\title{
RADIOWAVES PROPAGATION MODEL OF UNMANNED AERIAL SYSTEM DATA
}

${ }^{1}$ Department of Electronic Devices and Systems National Aviation University Kyiv, Ukraine,

${ }^{2,3}$ Department of Telecommunications Systems National Aviation University Kyiv, Ukraine E-mails: ${ }^{1}$ gab58@meta.ua, ${ }^{2,3}$ tks@ nau.edu.ua

\begin{abstract}
The offered model of radiowaves propagation of the unmanned aerial system data link is realized in two stages: calculation of middle radius of coverage area and his further elaboration by geometrical methods along the separate directions with the expressed relief inhomogeneities. Underestimation of this factor can be a reason of absence of receiving signal which leads to interruption of integrity of information, or can be an occasion of propagation of radiowaves beyond of destination area which creates a precondition of leaking or physical interception of information. The model allows to promote the level of informative integrity, availability and safety of data exchange due to a removal of propagation of radiowaves out of setting. Also it promotes reduction of probability of leaking and physical interception of information as well as retain of necessary level of availability and integrity of information.
\end{abstract}

Index Terms - Coverage area; model of propagation of radiowaves; base station; terminal; availability of information; integrity of information; interception of information; leaking of information.

\section{INTRODUCTION}

The development of unmanned aerial vehicles (UAV) with unmanned aerial systems (UAS) and related information technologies requires to ensure the confidentiality, integrity and availability of information. Quality of radiowaves propagation in data exchange systems affect these factors.

There are two ways to breach of the physical integrity and confidentiality of information in these systems.

1. Propagation over a distance which is greater than the required value for the sustainable operation of UAS data exchange system. This factor leads to a breach of confidentiality and radio intercept of data by the hostile, and respectively, to the loss of UAV control.

2. Propagation over a distance which is less than the required value. This factor leads to a breach of the conditions of access to information and to loss of data, which are transmitted from the UAV, as well as to the loss of UAV control.

Currently, the vast majority of telecommunications operators use of varieties of Okumura-Hata and COST-231 models for the forecast of distribution of radio waves. These models can determine only the so-called averaged propagation loss values and corresponding averaged radius of zone, and which are correct under the condition, that the coverage area has a circular shape. This occurs due to the fact, that these models take into account only the generic nature of the terrain, antenna height, working frequency, transmitter power and the distance to the observation point, and does not take into account such a phenomena as multi interference and diffraction on obstacles.

However, the real terrain contains a buildings, forests, mountains and other inhomogeneities, which are large in comparison with the wavelength, so the actual area has a significant deviation from the shape of a circle - so-called outbursts and failures. Therefore, the actual distance of stable connection can be several times greater or less than the predicted average value - for example, in the gorges, in the forests, on the dam of the mountains, and others. These factors can lead to a lack of communication with UAV, i.e. to the loss of availability of information, or propagation a data carrier on distance far exceeding the projected values, that can create conditions for the unauthorized interception of data.

These factors may adversely affect the integrity of information and security of wireless networks in the following aspects:

- the actual propagation of data carrier outside of a distance more or less than expected;

- the possibility of leakage of information or lack of it at the point of the reception;

- the creation of unacceptable levels of mutual interference that adversely affect the quality of data.

From these preliminary comments we make conclusions about the necessity for developing such methods of forecasting of coverage area that have a sufficient simplicity and would allow to take into account the inhomogeneities of the real terrain.

The research objective is elimination of possibilities of radio waves propagation out of limits of necessary distances, and also providing a stable propagation condition in UAS data link. 
The research problem is development of radiowaves propagation model, which will allow to consider the diffraction and interferential phenomena on land relief inhomogeneities. It will allow to increase forecasting accuracy of radiowaves propagation in real conditions, and to eliminate of possibilities of radio waves propagation outside of covering zones.

\section{PROBLEM STATEMENT}

The structure of mathematical model of propagation of radio waves is $P_{r}=L P_{t}$, where $P_{r}$ is the signal power in the reception antenna; $P_{t}$ is the transmitter radiation power; $L$ is the multiplier of weakening of radio waves. The task consists in development of multiplier $L$ definition technique, depending on diffraction and interferential losses in actual conditions of radio waves propagation. With use of value of $L$ it is possible to choose corresponding value of power of radiation $P_{t}$ for providing a stable communication in a necessary zone and for elimination of radio waves propagation outside a necessary zone.

\section{THE ANALYSIS OF LAST RESEARCHES}

The most common practical application of Okumura-Hata formula, which obtained from the numerical measurement of averaged power losses values in the propagation of radio waves $L$ as an equation with respect to distance radius zone $d$, is as follows [1]

$$
\begin{aligned}
& L=69,55+26,16 \log f-13,82 \log h_{1}-a\left(h_{2}\right) \\
&+\left(44,9-6,55 \log h_{1}\right) \log d-K,
\end{aligned}
$$

where $h_{1}$ is the height of the antenna control point, $\mathrm{m} ; h_{2}$ is the altitude of UAV, $\mathrm{m} ; d$ is the distance between the point of control and UAV, km; $f$ is the operating frequency, MHz; $a\left(h_{2}\right)$ is the height correction factor which depends on the frequency and is averaged by type of locality, i.e. city, suburb or village [1], [2]; $K$ is the extra weight coefficient for rural areas and suburbs whose value is given in [1], [2]. In practice, using this formula was established [3] that it underestimates the losses at frequencies of $1.5 \ldots 2 \mathrm{GHz}$ in a city or dense massif. So, later was offered "Augmented Model Hata" that has eliminated this deficiency. The main value of this model for the averaged propagation losses is

$$
\begin{array}{r}
L=46,33+\left(44,9-6,55 \log h_{1}\right) \log d+33,9 \log f \\
-a\left(h_{2}\right)-13,82 \log h_{1}+C,
\end{array}
$$

where weight coefficient $C=0$ for villages and suburbs, $C=3$ for the city or dense massif.

This model takes into account only the type of locality (town, suburb, village), but does not take into account the specific elevation of real obstacles which are hundreds of times more than the operating wave length. But on the real obstacles the radio waves experience of significant diffraction losses with the formation of significant "gaps" in the areas of attainability, and in the cross-sections or streets canyons the repeated reflection with a small difference in path length is the reason of multibeam interference phase to form multiple "emissions" in the range of attainability. Therefore, the most common method of forecasting of attainability by OkumuraHata model, which does not account for these phenomena, makes it impossible to predict the impact of specific parts of the terrain - mountains, slopes, ravines, clusters of houses, streets, etc. But this averaged prediction of coverage area could cause actual propagation outside the purpose limits or lack of it in the expected point of space with all the effects listed above. In addition, Okumura-Hata model and its modifications as COST-231 model limited the height position of the UAV antenna.

\section{PROBLEM SOLUTION}

For qualited forecasting of coverage area we offer computational procedure which is carried out in two stages. In the first stage, based on the values of the height of the control point antenna and UAV operating frequency, and the ratio between known values of transmitter power and receiver sensitivity on board, the average radius of the range is determined on the base of the Okumura-Hata model given above, according to the value of the average power loss in the propagation path of radio waves. In the second stage it takes into account the peculiarities of the terrain, for example:

- clusters of buildings, structures, slopes, etc., which cause diffraction losses and appropriated "failure" in the coverage area;

- availability of gorges, streets with tall buildings, in which there are cross-sections multibeam interference phenomena with the formation of "emissions" in the coverage area.

Thus, on the second phase of forecasting we offer to make specification of averaged distances values of stable connection in certain area, where there are the details of topography listed above, and which are ignored by the Okumura-Hata model and its modifications. Obviously, the specifying second stage requires such a propagation model which takes into account the diffraction on obstacles and multipath interference in a real location. Therefore, in the second stage we use the Walfisch-Ikegami forecasting model [1], [2]. It gives quite accurate results at frequencies from 0.8 to $5 \mathrm{GHz}$, and at distances from 20 to $10,000 \mathrm{~m}$. This model allows us to analyze 
separately two cases: propagation through the line of sight and in the "shaded" area out of sight. In conditions of line of sight Walfisch-Ikegami formula for distributing losses $L$ is:

$$
L=42,64+26 \log d+20 \log f,
$$

where $d$ is the distance to the reception point, $\mathrm{km} ; f$ is the operating frequency, $\mathrm{MHz}$.

For the region of space beyond the line of sight with the diffraction phenomenon, propagation losses consist of losses in free space $L_{\mathrm{fs}}$ and multiple diffraction losses $L_{\mathrm{md}}$. For these phenomena WalfischIkegami model is:

$$
L=\left\{\begin{array}{l}
L_{\mathrm{fs}}, \text { if } L_{\mathrm{fs}}+L_{\mathrm{md}}<0 ; \\
L_{\mathrm{fs}}+L_{\mathrm{md}}+L, \text { if } L_{\mathrm{fs}}+L_{\mathrm{md}}>0,
\end{array}\right.
$$

where $L_{\mathrm{fs}}$ are propagation losses in free space, defined by the formula

$$
L_{\mathrm{fs}}=32,45+20 \log d+20 \log f,
$$

$L_{\mathrm{md}}$ are multiple diffraction losses, which are determined by the formula

$$
L_{\mathrm{md}}=-16,9-10 \log n+10 \log f+20 \log \Delta h+L_{0} .
$$

In the last expression $n$ is the number of points of diffraction, $\Delta h$ is the value of exceeding line of sight by obstacle, $\mathrm{m} ; L_{0}$ are estimated losses, depending on the angle of diffraction as follows:

$$
L_{0}=\left\{\begin{array}{cl}
-10+0,354 \log \varphi, & 0 \leq \varphi \leq 35^{\circ} ; \\
2,5+0,075 \log \left(\varphi-35^{\circ}\right), & 35^{\circ} \leq \varphi \leq 55^{\circ} ; \\
4,0-0,114 \log \left(\varphi-55^{\circ}\right), & 55^{\circ} \leq \varphi \leq 90^{\circ} .
\end{array}\right.
$$

Obstacles height and distance between them along the direction of propagation are couted by additional factor of multiple losses $L_{\mathrm{m}}$ :

$$
L_{\mathrm{m}}=L_{\mathrm{sh}}+k_{a}+k_{d} \lg d+k_{f} \lg f-9 \lg b,
$$

where $k_{a}, k_{b}, k_{f}$ are extra weights that take into account losses depended on the distance and frequency for the conditions of the city, suburbs and villages, and which are determined by special nomograms provided in [2]; $b$ is the distance between obstacles, $\mathrm{m} ; L_{\mathrm{sh}}$ is the attenuation while propagation in the shadows zone:

$$
L_{\mathrm{sh}}= \begin{cases}-18 \log (1+\Delta h), & \Delta h>0 ; \\ 0, & \Delta h \leq 0 .\end{cases}
$$

To account for multibeam interference phenomena in the valley or the street alignment we propose the following procedure. Firstly, it is necessary to determine the presence of sight alignment in the gorge between the control point antenna and UAV. Next, it is need to determine the number of possible points of reflection $N$, depending on the length of the street (gorge). Tentatively it can be considered $N=$ 3 , since most of the radio waves reflect from the right and left walls of the gorge and the underlying surface. Thus, the estimated value of the multiplier multibeam interference $L_{\mathrm{mi}}$ can take a triple multiplier comparatively with value losses in free space $L_{\mathrm{fs}}$ :

$$
L_{\mathrm{mi}}=3 L_{\mathrm{fs}}=3(32,45+20 \log d+20 \log f) \text {. }
$$

The calculations showed that the magnitude of multiple losses increases to $30 \mathrm{~dB} /$ decade in the case when control point antenna location is below the obstacle level, and to $18 \mathrm{~dB} /$ decade when its location is above the obstacle level. In addition, multibeam interference phenomenon increases the value of multiple losses at least three times if the location of the control point antenna is in the alignment of the gorge. These values are very important, but when we use all kinds of models by OkumuraHata and COST-231 they are not considered at all.

An examination of the results shows, that the model of coverage area which considers the specific details of relief, unlike the existing models with calculations on the basis of average losses, make it possible to consider:

- the presence of cluster with one or more obstacles, which causes the diffraction losses and forms the "failure" zone within the coverage area;

- such a location of obstacles, that causes the multipath interference with the formation of "emissions" zone within the coverage area.

Thus, the proposed model of calculating of coverage area while designing telecommunications networks for UAS, unlike the existing ones, takes into account diffraction and interference phenomena that cause substantial dependence of stable connection distances on the direction of propagation.

\section{CONCLUSIONS}

The applying of the proposed model eliminates the undesirable effects that lead to breach of the integrity and confidentiality of information in the UAS communication link.

1. Propagation over a distance which is greater than the required value for the sustainable operation of UAS data exchange system. This factor leads to a breach of confidentiality and radio intercept of data by the hostile, and respectively, to the loss of UAV control.

2. Propagation over a distance which is less than the required value. This factor leads to a breach of the conditions of access to information and to loss of 
data, which are transmitted from the UAV, as well as to the loss of UAV control.

Results of researches allow to use the value of a multiplier of weakening of radio waves for a choice of such values of the transmitter power, the receiver sensitivity and their working frequencies, at which possibility of information leakage and its interception is eliminated, also the stable communication and integrity of information in UAS data link are provided within a necessary zone.

\section{REFERENCES}

[1] Ye. Gabrousenko, V. Pavlov, D. Zakharov, and A. Mensha "Minimizing of the coverage area differences in the base-terminal and terminal-base directions in the cellular communication system", in Protection of information, Special edition, Kyiv: NAU, 2008, pp. 25-31.

[2] "Prediction procedure for the evaluation of interference between stations on the surface of the Earth at frequencies above about $0.1 \mathrm{GHz}$ ", ITU-R 452-14, October 2009.

Received July, 122015

\title{
Model of ground control coverage area
}

\author{
Gabrusenko Yevgen. . Associate Professor. \\ Radioelectronics Devises and Systems Department, National Aviation University, Kyiv, Ukraine. \\ Education: Kyiv Institute of Civil Aviation Engineers, Kyiv, Ukraine (1985). \\ Research area: Air Navigation, Technical Electrodynamics, Electromagnetic Compatibility of Radioelectronics Sys- \\ tems. \\ Publications: more than 60 papers. \\ E-mail: gab58@meta.ua
}

\section{Machalin Igor}

Telecommunications Systems Department, Institute of Aeronavigation, National Aviation University, Kyiv, Ukraine. Education: Kyiv Institute of Civil Aviation Engineers, Kyiv, Ukraine (19__).

Research area: Air Navigation, Telecommunications Systems, Diagnostics of Radio Systems.

Publications: more than papers.

E-mail: tks@nau.edu.ua

\section{Taranenko Anatolij}

Telecommunications Systems Department, Institute of Aeronavigation, National Aviation University, Kyiv, Ukraine. Education: Kyiv Institute of Civil Aviation Engineers, Kyiv, Ukraine (1979).

Research area: Air Navigation, Telecommunications Systems, Diagnostics of Radio Systems.

Publications: more than 50 papers.

E-mail: tks@nau.edu.ua

С. І. Габрусенко, І. А. Мачалін, А. Г. Тараненко. Модель поширення радіохвиль в каналах передачі даних безпілотних літальных систем

\section{Модель поширення радіохвиль даних безпілотних літальних систем}

Запропоновано модель поширення радіохвиль в каналі передачі даних безпілотної авіаційної системи. Модель реалізована в два етапи: розрахунок середнього радіусу зони покриття та ії подальша розробка за геометричними методами уздовж окремих напрямів з вираженими неоднорідностями рельєфу. Недооцінка цього чинника може бути причиною відсутності приймання сигналу, що призводить до погіршення цілісності інформації, або може бути причиною поширення радіохвиль за межі району призначення, що створює передумову витоку або фізичного перехоплення інформації. Модель дозволяє підвищити рівень інформаційної цілісності, доступності та безпеки обміну даними за рахунок виключення поширення радіохвиль за встановлені межи. Це дозволить знизити ймовірність витоку і перехоплення інформації, а також сприяє збереженню необхідного рівня доступності та цілісності інформації

Ключові слова: зона покриття; модель поширення радіохвиль; базова станція; термінал; доступність інформації; цілісність інформації; перехоплення інформації; витік інформації.

Габрусенко Свген Ігорович. Кандидат технічних наук. Доцент.

Кафедра радіоелектронних пристроїв та систем, Національний авіаційний університет, Київ, Україна.

Освіта: Київський інститут інженерів цивільної авіації, Київ, Україна (1985).

Напрям наукової діяльності: аеронавігація, технічна електродинаміка, електромагнітна сумісність радіоелектронних засобів. 
Кількість публікацій: більше 60 наукових робіт.

E-mail: gab58@ meta.ua

Мачалін Ігор Олексійович.

Кафедра телекомунікаційних систем, Інститут аеронавігації, Національний авіаційний університет, Київ, Україна.

Освіта: Київський інститут інженерів цивільної авіації, Київ, Україна (19__).

Напрям наукової діяльності: аеронавігація, телекомунікаційні системи, діагностика радіотехнічних систем.

Кількість публікацій: більше

E-mail: tks@nau.edu.ua

Тараненко Анатолий Григорьевич.

Кафедра телекомунікаційних систем, Інститут аеронавігації, Національний авіаційний університет, Київ, Україна.

Освіта: Київський інститут інженерів цивільної авіації, Київ, Україна (1979).

Напрям наукової діяльності: аеронавігація, телекомунікаційні системи, діагностика радіотехнічних систем.

Кількість публікацій: більше 50 наукових рабіт.

E-mail: tks@nau.edu.ua

Е. И. Габрусенко, И. А. Мачалин, А. Г. Тараненко. Модель распространения радиоволн в каналах передачи данных беспилотных летательных систем

Предложена модель распространения радиоволн в канале передачи данных беспилотной авиационной системы. Модель реализована в два этапа: расчет среднего радиуса зоны покрытия и ее дальнейшая разработка по геометрическим методам вдоль отдельных направлений с выраженными неоднородностями рельефа. Недооценка этого фактора может быть причиной отсутствия приема сигнала, что приводит к нарушению целостности информации, или может быть причиной распространения радиоволн за пределы района назначения, которая создает предпосылку утечки или физического перехвата информации. Модель позволяет повысить уровень информационной целостности, доступности и безопасности обмена данными за счет исключения распространения радиоволн за пределы установленных границ. Это позволит снизить вероятность утечки и перехвата информации, и способствует сохранению необходимого уровня доступности и целостности информации.

Ключевые слова: зона покрытия; модель распространения радиоволн; базовая станция; терминал; доступность информации; целостность информации; перехват информации; утечка информации.

Габрусенко Евгений Игоревич. Кандидат технических наук. Доцент.

Кафедра радиоэлектронных устройств и систем, Национальный авиационный университет, Киев, Украина.

Образование: Киевский институт инженеров граждансокй авиации, Киев, Украина (1985).

Направление научной деятельности: аэронавигация, техническая электродинамика, электромагнитная совместимость радиоэлектронных средств.

Количество публикаций: более 60 научных работ.

E-mail: gab58@meta.ua

\section{Мачалин Игорь Алексеевич.}

Кафедра телекоммуникационных систем, Институт аэронавигации, Национальный авиационный университет, Киев, Украина.

Образование: Киевский институт инженеров гражданской авиации, Киев, Украина (19__).

Направление научной деятельности: аэронавигация, телекоммуникационные системы, диагностика радиотехнических систем.

Количество публикаций: более научных работ.

E-mail: $\underline{\text { tks@nau.edu.ua }}$

\section{Тараненко Анатолий Григорьевич.}

Кафедра телекоммуникационных систем, Институт аэронавигации, Национальный авиационный университет, Киев, Украина.

Образование: Киевский институт инженеров гражданской авиации, Киев, Украина (1979).

Направление научной деятельности: аэронавигация, телекоммуникационные системы, диагностика радиотехнических систем.

Количество публикаций: более 50 научных работ.

E-mail: tks@nau.edu.ua 